\title{
Inheritance of aluminum tolerance in maize
}

\author{
R. MAGNAVACA, \\ National Corn and Sorghum Research Center, EMBRAPA, C.P. 151, 35,700 Sete Lagoas, M.G., \\ Brazil \\ C.O. GARDNER and R.B. CLARK \\ Department of Agronomy and U.S. Department of Agriculture, Agricultural Research Service, \\ University of Nebraska, Lincoln, NE 68583, USA
}

Key words Additive effects Backcrosses Dominance effects Epistasis $F_{2}$ generations General and specific combining abilities Heterosis Relative seminal root length Zea mays

\begin{abstract}
Summary The inheritance of $\mathrm{Al}$ tolerance in maize (Zea mays $\mathrm{L}$.) was studied in nutrient solution. Analysis of relative seminal root lengths of six generations $\left(\mathrm{P}_{1}, \mathrm{P}_{2}, \mathrm{~F}_{1}, \mathrm{~F}_{2}, \mathrm{BC}_{1}\right.$, and $\left.\mathrm{BC}_{2}\right)$ derived from crosses between tolerant and non-tolerant inbred lines showed that additive gene effects contributed most to genetic variation for Al tolerance of the materials included in this study. Dominance effects accounted for only half as much variation as did additive effects. Effects of epistasis contributed little compared to other gene effects. The frequency distributions of plants within the $F_{2}$ generations were continuous, unimodal, and typical for quantitatively inherited traits. There was some tendency for non-tolerance to be dominant over tolerance, but it was not consistent. In a diallel cross among inbred lines, the analysis of $F_{1}$ crosses indicated that the variance for general combining ability explained most of the variation, but specific combining ability was statistically significant in each case.
\end{abstract}

\section{Introduction}

The inheritance of $\mathrm{Al}$ tolerance in maize (Zea Mays L.) has been studied by several authors using different techniques to induce and assess Al toxicity ${ }^{8,9,14,19,22,24,25}$. Rhue et al. ${ }^{22}$ grew plants of $F_{2}$ generations and the backcrosses of more sensitive parental lines in nutrient solutions with $250 \mu \mathrm{mol} \mathrm{Al} \mathrm{L} \mathrm{L}^{-1}\left(126 \mu \mathrm{mol} \mathrm{P} \mathrm{L}^{-1}\right)$ at different concentrations of $\mathrm{Ca}$. Because of the tendency for a 3:1 segregation in the $F_{2}$ generations and a 1:1 segregation in the backcross generations among the maize inbred lines, they concluded that Al tolerance was controlled by a single locus. However, additional evidence by these authors indicated control of $\mathrm{Al}$ tolerance to be by a multiple allelic series ${ }^{21}$.

Three tolerant and two non-tolerant maize lines were used to develop $\mathrm{F}_{1}, \mathrm{~F}_{2}$, and backcross generations studied by Garcia et al. ${ }^{9}$. Seeds from these generations were planted in sand and irrigated with nutrient solution containing 0 and $2780 \mu \mathrm{mol} \mathrm{Al} \mathrm{L}{ }^{-1}$. Seven days after germination, root lengths of seedlings grown with and without $\mathrm{Al}$ were measured to determine relative root lengths among the genotypes. The three $F_{1}$ hybrids studied and their backcrosses to the Al tolerant parents were relatively tolerant to $\mathrm{Al}$. Backcrosses to the non-tolerant parents showed 
an approximate 1:1 segregation. In the $\mathrm{F}_{2}$ generations, a bimodal distribution was observed with approximately a 3:1 segregation. These investigators concluded that $\mathrm{Al}$ tolerance in maize was controlled by a single dominant gene with possible alterations by modifiers.

Variance component estimates for Al tolerance were determined for the maize variety 'Piranao"8. A total of 144 progenies were produced according to the Comstock and Robinson ${ }^{3}$ mating design I. Progenies were evaluated in a pot experiment with an acid soil. Based on shoot and root dry weights, it was reported that the most important component of genetic variability was dominance variance.

Naspolini et al. ${ }^{19}$ obtained estimates of general and specific combining abilities from a diallel cross of 10 inbred maize lines previously selected for Al tolerance. The 45 possible single crosses were tested in a field experiment on acid soil with three levels of $\mathrm{Al}$ saturation $(0,45$, and $64 \%$ ). The estimates of the combining ability variances for grain yield were signficant even though they were variable among Al saturation levels. The magnitudes of general combining ability variances were higher than those of the specific combining ability variances, indicating the importance of additive gene effects.

Maize populations were tested for Al tolerance using nutrient solutions in a complete diallel cross involving the parental populations, $\mathrm{F}_{1}$ crosses, and reciprocals ${ }^{14}$. The variance for general combining ability explained most of the variation, but specific combining ability was also significant.

Since information is somewhat limited, a better understanding of the genetic control of $\mathrm{Al}$ tolerance in maize is needed. Such information would be useful to help evaluate the potential of improving maize through selection and to greatly improve the efficiency of breeding programs aimed at helping to solve maize production problems in $\mathrm{Al}$ toxic acid soils. The objective of the research reported here was to obtain additional information on the inheritance of $\mathrm{Al}$ tolerance in maize and to assess the relative importance of additive and dominance effects and epistasis on $\mathrm{Al}$ tolerance.

\section{Materials and methods}

\section{Growth of plants}

Captan [N-(trichloromethylthio)-4-cyclohexene-1,2-dicarboximide] treated maize seeds were germinated between rolled paper towels kept moist with aerated water. Seven-day-old uniform sized seedlings without visual root injury were transferred to a plastic plate ( 42 plants per plate) and grown in $6.5 \mathrm{~L}$ of aerated nutrient solution containing $185 \mu \mathrm{mol} \mathrm{Al} \mathrm{L}-1$ as $\mathrm{KAl}\left(\mathrm{SO}_{4}\right)_{2}$. The nutrient solution and techniques used for growing plants have been described ${ }^{1,15}$. The composition of the nutrient solution $\left(\mu \mathrm{mol}\right.$ element $\mathrm{L}^{-1}$ ) was $10900 \mathrm{NO}_{3}-\mathrm{N}, 3500 \mathrm{Ca}, 2300 \mathrm{~K}, 1300 \mathrm{NH}_{4}-\mathrm{N}, 850 \mathrm{Mg}$, $590 \mathrm{Cl}, 580 \mathrm{~S}, 45 \mathrm{P}, 25 \mathrm{~B}, 9.1 \mathrm{Mn}, 2.29 \mathrm{Zn}, 0.83 \mathrm{Mo}, 0.63 \mathrm{Cu}$, and $77 \mathrm{Fe}$ as FeHEDTA (ferric hydroxyethyl-ethylenediaminetriacetate). The $\mathrm{pH}$ of nutrient solutions was adjusted initially to 
$4.0 \pm 0.1$ and maintained at this $\mathrm{pH}$ throughout the experiment. Water was added daily to maintain solution volumes.

Plants were grown in a controlled environment room with $16 \mathrm{~h}$ light at $27 \pm 1{ }^{\circ} \mathrm{C}$ and $8 \mathrm{~h}$ darkness at $19 \pm 1^{\circ} \mathrm{C}$. The photosynthetic photon flux density was $150 \mu \mathrm{E} \mathrm{m}^{-2} \mathrm{~s}^{-1}$ at plant height $(40 \mathrm{~cm}$ below the lamps) provided by fluorescent lamps (Agro-Life cool white, F40)*.

\section{Handling of plants and traits measured to assess Al tolerance}

When seedlings were transferred to treatment solutions, the initial lengths of seminal roots were measured. Plant were grown in $\mathrm{Al}$ treatment solutions for 10 days, when the experiments were terminated and the final seminal root lengths measured. Relative seminal root length (RSRL) was used to evaluate plants for $\mathrm{Al}$ tolerance. RSRL values were determined by dividing the final seminal root length by the initial length. This trait was chosen to assess $\mathrm{Al}$ tolerance because it has been found to be one of the better traits to assess $\mathrm{Al}$ toxicity ${ }^{6,16}$. The greater the RSRL value, the greater the $\mathrm{Al}$ tolerance.

\section{Germplasm, experimental design, and statistical analysis of experiments}

Experiment 1. Six generations $\left(\mathrm{P}_{1}, \mathrm{P}_{2}, \mathrm{~F}_{1}, \mathrm{~F}_{2}, \mathrm{BC}_{1}, \mathrm{BC}_{2}\right)$ from each of six sets of crosses $(\mathrm{B} 37 \times \mathrm{A} 635, \mathrm{~B} 37 \times \mathrm{C} 103, \mathrm{Mo17} \times \mathrm{B} 37, \mathrm{Mo} 17 \times \mathrm{H} 84, \mathrm{~W} 117 \times \mathrm{A} 554$, and W117 $\times \mathrm{A} 635)$ were used. The experimental design was a modified randomized complete block with three replications. Mean RSRL values were determined using six plants per plot, except for the $F_{2}$ generation in which 12 plants per plot were used.

Subdivision of the degrees of freedom and sums of squares for generations within each set were handled according to Mather and Jink ${ }^{17}$ generation means model. The following coefficients for parameters of the complete model were used to obtain the sums of squares:

\begin{tabular}{llrllll}
\hline Generation & \multicolumn{6}{l}{ Coefficients for parameters } \\
\cline { 2 - 7 } & $\mathrm{m}$ & {$[\mathrm{d}]$} & {$[\mathrm{h}]$} & {$[\mathrm{i}]$} & {$[\mathrm{j}]$} & {$[\mathrm{l}]$} \\
\hline $\mathrm{P}_{1}$ & 1 & 1 & 0 & 1 & 0 & 0 \\
$\mathrm{P}_{2}$ & 1 & -1 & 0 & 1 & 0 & 0 \\
$\mathrm{~F}_{1}$ & 1 & 0 & 1 & 0 & 0 & 1 \\
$\mathrm{~F}_{2}$ & 1 & 0 & $1 / 2$ & 0 & 0 & $1 / 4$ \\
$\mathrm{BC}_{1}$ & 1 & $1 / 2$ & $1 / 2$ & $1 / 4$ & $1 / 4$ & $1 / 4$ \\
$\mathrm{BC}_{2}$ & 1 & $-1 / 2$ & $1 / 2$ & $1 / 4$ & $-1 / 4$ & $1 / 4$ \\
\hline
\end{tabular}

where $\mathrm{m}=$ the mean of the two parents; $[\mathrm{d}]=$ the cumulative additive gene effects; $[\mathrm{h}]=$ the cumulative dominance gene effects; $[\mathrm{i}]=$ the cumulative additive $\times$ additive epistatic effects; $[\mathrm{j}]=$ the cumulative additive $\times$ dominance epistatic effects and $[1]=$ the cumulative dominance $\times$ dominance epistatic effects.

The estimates of the six parameters were obtained by using the equations:

$$
\begin{aligned}
& \mathrm{m}=1 / 2 \overline{\mathrm{P}}_{1}+1 / 2 \overline{\mathrm{P}}_{2}+4 \overline{\mathrm{F}}_{2}-2 \overline{\mathrm{BC}}_{1}-2 \overline{\mathrm{BC}}_{2} \\
& {[\mathrm{~d}]=1 / 2 \overline{\mathrm{P}}_{1}-1 / 2 \overline{\mathrm{P}}_{2}} \\
& {[\mathrm{~h}]=6 \overline{\mathrm{BC}}_{1}+6 \overline{\mathrm{BC}}_{2}-8 \overline{\mathrm{F}}_{2}-\overline{\mathrm{F}}_{1}-3 / 2 \overline{\mathrm{P}}_{1}-3 / 2 \overline{\mathrm{P}}_{2}} \\
& {[\mathrm{i}]=2 \overline{\mathrm{BC}}_{1}+2 \overline{\mathrm{BC}}_{2}-4 \overline{\mathrm{F}}_{2}} \\
& {[\mathrm{j}]=2 \overline{\mathrm{BC}}_{1}-\overline{\mathrm{P}}_{1}-2 \overline{\mathrm{BC}}_{2}+\overline{\mathrm{P}}_{2}} \\
& {[\mathrm{l}]=\overline{\mathrm{P}}_{1}+\overline{\mathrm{P}}_{2}+2 \overline{\mathrm{F}}_{1}+4 \overline{\mathrm{F}}_{2}-4 \overline{\mathrm{BC}}_{1}-4 \overline{\mathrm{BC}}_{2} .}
\end{aligned}
$$

* Mention of a company, trademark, or proprietary product does not constitute a guarantee or warranty of the product by the University of Nebraska or the U.S. Department of Agriculture, and does not imply its approval to the exclusion of other products that may also be suitable. 
Experiment 2. Four sets of $\mathrm{F}_{2}$ progenies involving maize parental lines in the crosses A554 $\times$ W117, B37 $\times$ A635, B37 $\times$ C103, and Mo17 $\times$ H84 were used. The experimental design was a randomized complete block with four replications. The statistical analysis of RSRL values was conducted using indidivual plant data.

Experiment 3. Eight parental inbred maize lines (A554, A635, B37, C103, C164, H84, Mol7, and W117) and progenies of their diallel crosses ( $28 \mathrm{~F}_{1}$ crosses without reciprocals) were tested for $\mathrm{Al}$ tolerance in nutrient solutions. The experimental design was a $6 \times 6$ triple lattice (three replications). The lattice analysis for RSRL was performed according to procedures outlined by Cochran and $\operatorname{Cox}^{2}$. Based on the effective error variance from the lattice analysis and the experimental error from the randomized complete block analysis, the relative efficiency of the lattice was determined. Where the relative efficiency of the lattice was less than $10 \%$, the data were analyzed as a randomized complete block design and means were not adjusted.

Since the 36 treatments consisted of $28 F_{1}$ progenies and eight parental lines, the sum of squares for treatments was subdivided into parents, parents $v s$. crosses, and among crosses according to procedures of Gardner and Eberhart ${ }^{10}$. The parents were excluded from the diallel cross part of the analysis which was then analyzed according to experimental method No. 4 of Griffing ${ }^{11}$, involving one set of $F_{1}$ progenies with no parents and excluding reciprocal crosses. Only the $p(p-1) / 2$ ( $p=$ number of parental inbred maize lines) different $F_{1}$ mean values were used in estimating general and speciifc combining ability variances.

\section{Results and discussion}

\section{Experiment 1}

Means of RSRL values measured in the different generations of six crosses are presented in Table 1 . In Sets 1 and 2, $F_{1}, F_{2}$, and backcross generations were similar to the susceptible parents, but in Sets 3, 4, 5, and 6 , the $\mathrm{F}_{1}, \mathrm{~F}_{2}$, and backcross generations were similar to the more $\mathrm{Al}$ tolerant parents. The greatest amount of heterosis was exhibited in Sets 3 and 5.

The analysis of variance for the RSRL values measured in different generations of the six crosses (Table 2) indicated statistical significance among generation means in all six sets. Subdivision of the sums of squares for generations within sets into those attributable to each of the different kinds of gene effects is presented in Table 3. Estimates of genetic parameters in each set are shown in Table 4.

Table 1. Mean relative seminal root lengths (RSRL) measured in different generations derived from six maize crosses and grown in nutrient solutions (Experiment 1)

\begin{tabular}{lllllll}
\hline Set & Generation & & & & \\
\cline { 2 - 7 } & $\mathrm{P}_{1}$ & $\mathrm{P}_{2}$ & $\mathrm{~F}_{1}$ & $\mathrm{~F}_{2}$ & $\mathrm{BC}_{1}$ & $\mathrm{BC}_{2}$ \\
\hline 1 & $\frac{\mathrm{B} 37}{1.24}$ & $\frac{\mathrm{A} 635}{1.62}$ & 1.20 & 1.32 & 1.26 & 1.37 \\
2 & $\frac{\mathrm{C} 103}{1.65}$ & $\frac{\mathrm{B} 37}{1.21}$ & 1.24 & 1.24 & 1.25 & 1.19 \\
3 & $\frac{\mathrm{W} 117}{1.42}$ & $\frac{\mathrm{A} 635}{1.69}$ & 1.74 & 1.59 & 1.55 & 1.63 \\
4 & $\frac{\mathrm{Mo1}}{1.33}$ & $\frac{\mathrm{B} 37}{1.25}$ & 1.39 & 1.35 & 1.44 & 1.43 \\
5 & $\frac{\mathrm{A} 554}{1.24}$ & $\frac{\mathrm{W} 117}{1.35}$ & 1.48 & 1.39 & 1.41 & 1.55 \\
6 & $\frac{\mathrm{H} 84}{1.64}$ & $\frac{\mathrm{Mol}}{1.29}$ & 1.54 & 1.52 & 1.46 & 1.39 \\
\hline
\end{tabular}


Table 2. Analysis of variance of relative seminal root length (RSRL) obtained from six maize generations derived from six different crosses grown in nutrient solutions (Experiment 1)

\begin{tabular}{lrl}
\hline Source of variation & df & Mean squares \\
\hline Replications & 2 & 0.0124 \\
Sets & 5 & $0.2188^{* *}$ \\
Replications $\times$ sets & 10 & 0.0032 \\
Generations within sets & 30 & $0.0486^{* *}$ \\
$\quad$ Generations within Set 1 & 5 & $0.0688^{* *}$ \\
Generations within Set 2 & 5 & $0.0914^{* *}$ \\
Generations within Set 3 & 5 & $0.0373^{* *}$ \\
Generations within Set 4 & 5 & $0.0163^{* *}$ \\
Generations within Set 5 & 5 & $0.0341^{* *}$ \\
$\quad$ Generations within Set 6 & 5 & $0.0437^{* *}$ \\
Error & 60 & 0.0030 \\
Total & 107 & 3.9 \\
CV $(\%)$ & & \\
\hline
\end{tabular}

** Statistical significance at $\alpha=0.01$.

Sets 1, 2, 3, and 6 involved generations derived from crosses between tolerant and non-tolerant lines. In these sets, additive gene effects explained most of the genetic variation, but dominance contributed a significant amount of variance except in Set 6. Dominance accounted for about half as much of the total genetic variance as did additive gene effects in Sets 1, 2, and 3. Epistasis was significant in Sets 2 and 6. Each of the three kinds of epistasis variance in Set 2 was significant, although small compared to the variances due to additive and dominance effects. Dominance $\times$ dominance epistasis was significant in Set 6 , but it was small compared to the variance due to additive effects. The model with epistasis effects included substantially increased the amount of genetic variance that could be explained compared to the model with only additive and dominance effects, except for Set 1 (see multiple $r^{2}$ values in Table 4).

Table 3. Mean squares of relative seminal root length (RSRL) obtained from six maize generations derived from six different sets (Experiment 1)

\begin{tabular}{llllllll}
\hline Source of variation $^{\dagger}$ & df & \multicolumn{6}{l}{ Mean squares of set nos. } \\
\cline { 3 - 8 } & & 1 & 2 & 3 & 4 & 5 & 6 \\
\hline Generations within set & 5 & $0.06880^{* *}$ & $0.0914^{* *}$ & $0.0373^{* *}$ & $0.0163^{* *}$ & $0.0341^{* *}$ & $0.0437^{* *}$ \\
Additive & 1 & $0.22188^{* *}$ & $0.2688^{* *}$ & $0.1128^{* *}$ & 0.0994 & $0.0382^{* *}$ & $0.1733^{* *}$ \\
Dominance & 1 & $0.1114^{* *}$ & $0.1107^{* *}$ & $0.0568^{* *}$ & $0.0351^{* *}$ & $0.0904^{* *}$ & 0.0080 \\
Epistasis & 3 & 0.00270 & $0.0258^{* *}$ & 0.0056 & $0.0123^{*}$ & $0.0140^{* *}$ & $0.0124^{* *}$ \\
$\quad$ Additive $\times$ additive & 1 & 0.00001 & $0.0319^{* *}$ & 0.0110 & 0.0040 & 0.0041 & 0.0008 \\
$\quad$ Additive $\times$ dominance & 1 & 0.00800 & $0.0314^{* *}$ & 0.0034 & 0.0012 & 0.0097 & 0.0116 \\
$\quad$ Dominance $\times$ dominance & 1 & 0.00007 & $0.0141^{*}$ & 0.0024 & $0.0318^{* *}$ & $0.0283^{* *}$ & $0.0249^{* *}$ \\
\hline
\end{tabular}

$*$, ** Statistical significance at $\alpha=0.05$, and $\alpha=0.01$, respectively.

${ }^{+}$Parameters defined by Mather and Jinks ${ }^{17}$. 
Table 4. Estimates of the additive, dominance, and epistasis effects for relative seminal root length (RSRL) obtained from six maize generations derived from six different sets (Experiment 1)

\begin{tabular}{lcccccc}
\hline Set model ${ }^{\dagger}$ & Additive & Dominance & $\begin{array}{l}\text { Additive } \times \\
\text { additive }\end{array}$ & $\begin{array}{l}\text { Additive } \times \\
\text { dominance }\end{array}$ & $\begin{array}{l}\text { Dominance } \times \\
\text { dominance }\end{array}$ & $\begin{array}{l}\text { Multiple } \\
\mathrm{R}^{2} 100(\%)\end{array}$ \\
\hline Set 1 & & & & & - & \\
3 Parameters & -0.172 & -0.232 & - & - & - & 92.7 \\
6 Parameters & -0.188 & -0.295 & -0.027 & 0.163 & 0.037 & 94.9 \\
Set 2 & & & & & & \\
3 Parameters & 0.189 & -0.228 & - & - & - & 80.5 \\
6 Parameters & 0.222 & 0.762 & -0.067 & -0.323 & 0.503 & 96.9 \\
Set 3 & & & & & & \\
3 Parameters & -0.123 & 0.163 & - & - & - & 61.3 \\
6 Parameters & -0.133 & -0.010 & 0.013 & 0.107 & 0.207 & 88.5 \\
Set 4 & & & & & & \\
3 Parameters & 0.035 & 0.129 & - & - & - & 34.7 \\
6 Parameters & 0.042 & 1.228 & 0.367 & -0.063 & -0.757 & 62.2 \\
Set 5 & & & & & & \\
3 Parameters & -0.073 & 0.206 & - & - & - & 67.3 \\
6 Parameters & -0.053 & 1.237 & 0.340 & -0.180 & -0.713 & 89.0 \\
Set 6 & & & & & & \\
3 Parameters & 0.152 & 0.061 & - & - & - & 70.9 \\
6 Parameters & 0.172 & -0.952 & -0.360 & -0.197 & 0.670 & 83.6 \\
\hline
\end{tabular}

${ }^{+}$Parameters defined by Mather and Jinks ${ }^{17}$.

‡ The 3 parameter model excludes epistasis; the six parameter model includes epistasis.

In crosses between lines susceptible to $\mathrm{Al}$ (sets 4 and 5), dominance gene effects and dominance $\times$ dominance epistasis explained most of the genetic variation. Additive gene effects were of some importance in Set 5 , but not in Set 4 .

\section{Experiment 2}

The four $\mathrm{F}_{2}$ progenies of single crosses A554 $\times \mathrm{W} 117, \mathrm{~B} 37 \times \mathrm{A} 635$, $\mathrm{B} 37 \times \mathrm{C} 103$, and Mo17 $\times \mathrm{H} 84$ (Sets 1, 2, 5, and 6 of Experiment 1) differed in their mean $\mathrm{Al}$ tolerance when grown in nutrient solutions (Table 5). They also differed in the amount of plant-to-plant variation within the $\mathrm{F}_{2}$ generations; Mo17 $\times \mathrm{H} 84$ had the greatest variance and $\mathrm{B} 37 \times \mathrm{C} 103 \mathrm{had}$ the least. The magnitude of the variances among plants within $\mathrm{F}_{2}$ generations was not related to the magnitude of the differences between their parents in $\mathrm{Al}$ tolerance. A554 and W117 differed the least in RSRL values (0.11, Table 1$)$, but had next to the highest variance in their $\mathrm{F}_{2}$ generation; and $\mathrm{B} 37$ and $\mathrm{C} 103$ differed the most (0.44), but had the lowest $F_{2}$ generation variance. The two crosses involving B37 had the lowest variances among $\mathrm{F}_{2}$ generation plants.

The frequency distributions of the $\mathrm{F}_{2}$ generations are presented in 
Table 5. Analysis of variance for relative seminal root length (RSRL) in $\mathrm{F}_{2}$ maize generations of four different crosses grown in nutrient solutions (Experiment 2)

\begin{tabular}{lrl}
\hline Source of variation & df & Mean squares \\
\hline Replications & 3 & 0.0088 \\
$\mathrm{~F}_{2}$ generations & 3 & $0.0420^{* *}$ \\
Error & 9 & 0.0017 \\
Total & 15 & 3.1 \\
$\mathrm{CV}(\%)$ & & \\
Among plants & 656 & 0.0259 \\
$\mathrm{~F}_{2}$ generation 1 $(\mathrm{B} 37 \times \mathrm{A} 635)$ & 164 & 0.0185 \\
$\mathrm{~F}_{2}$ generation 2 $(\mathrm{B} 37 \times \mathrm{C} 103)$ & 164 & 0.0163 \\
$\mathrm{~F}_{2}$ generation 3 $(\mathrm{A} 554 \times \mathrm{W} 117)$ & 164 & 0.0294 \\
$\mathrm{~F}_{2}$ generation 4 $(\mathrm{Mo17} \times \mathrm{H} 84)$ & 164 & 0.0397 \\
\hline
\end{tabular}

** Statistical significance at $\alpha=0.01$.

Figure 1. The figure shows susceptible plants were more frequent than tolerant ones. The highest frequencies of Al-tolerant plants occurred in the cross involving Mo17 $\times \mathrm{H} 84$. All frequency distributions were continuous, unimodal, and typical for a quantitatively inherited trait. Higher frequencies in the susceptible ranges for three crosses (numbers closer to 1.0), indicated a preponderance of genes dominant for susceptibility to Al tolerance. Plants in the $\mathrm{F}_{2}$ generation of Mo17 $\times \mathrm{H} 84$ showed the most nearly normal distribution.

\section{Experiment 3}

The analysis of variance for RSRL of eight parental lines and their 28 single-cross hybrids (diallel crosses) grown in nutrient solution are

Table 6. Analysis of variance for relative seminal root length (RSRL) in eight maize parents and their $28 \mathrm{~F}_{1}$ crosses (diallel) grown in nutrient solution (Experiment 3)

\begin{tabular}{lrc}
\hline Source of variation & df & Mean squares \\
\hline Replications & 2 & 0.0121 \\
Treatments (unadj.) & 35 & $0.3301^{* *}$ \\
$\quad$ Parents & 7 & $0.1778^{* *}$ \\
Parents $v$ crosses & 1 & $1.5699^{* *}$ \\
Crosses & 27 & $0.3237^{* *}$ \\
$\quad$ General combining ability & 7 & $0.8911^{* *}$ \\
$\quad$ Specific combining ability & 20 & $0.1251^{* *}$ \\
RCBD error & 70 & 0.0481 \\
Blocks within replications (adj.) & 15 & 0.0544 \\
Intra-block error & 55 & 0.0464 \\
Total & 107 & 0.0479 \\
Average effective error & & 100.4 \\
Relative efficiency of lattice (\%) & & 11.8 \\
CV (\%) & & \\
\hline
\end{tabular}

** Statistical significance at $\alpha=0.01$. 

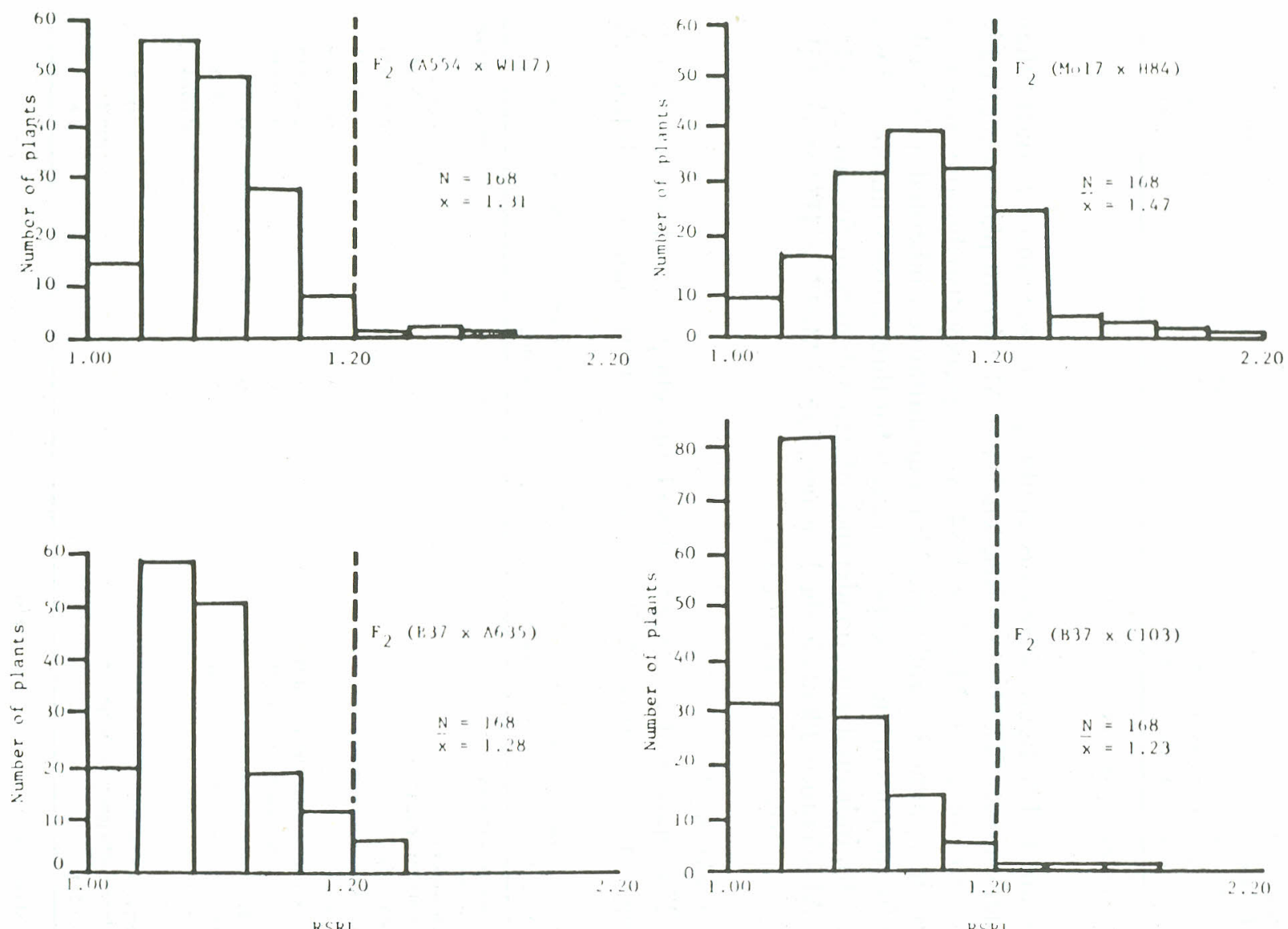

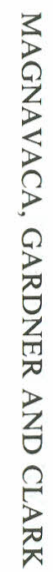

Fig. 1. Frequency distributions for relative $s \quad$ al root length (RSRL) of plants from four different $\mathrm{F}_{2}$ maize ge 2). (The dotted line represents genotypes considered to have good Al tolerance). 
Table 7. Parental and $F_{1}$ means for relative seminal root length (RSRL) of maize grown in nutrient solution (Experiment 3)

\begin{tabular}{lllllllllll}
\hline $\begin{array}{l}\text { Inbred } \\
\text { lines }\end{array}$ & \multicolumn{2}{l}{$\mathrm{F}_{1}$ means } & & & & & & & & $\begin{array}{l}\text { Parental }^{\dagger} \\
\text { means }\end{array}$ \\
\cline { 2 - 10 } & Mo17 & C103 & H84 & CI64 & B37 & W117 & A635 & A554 & $\begin{array}{l}\text { Cross } \\
\text { mean }\end{array}$ \\
\hline Mo17 & 1.75 & 1.67 & 1.75 & 1.64 & 1.46 & 1.78 & 1.99 & 1.72 & $1.57 \mathrm{bcde}$ \\
C103 & & 1.81 & 1.82 & 1.72 & 1.63 & 1.85 & 2.37 & 1.85 & $2.06 \mathrm{a}$ \\
H84 & & & 2.23 & 1.55 & 1.92 & 1.85 & 2.67 & 1.96 & $1.79 \mathrm{ab}$ \\
C164 & & & & 1.79 & 2.13 & 2.01 & 2.83 & 2.08 & $1.74 \mathrm{abc}$ \\
B37 & & & & & 1.78 & 1.49 & 1.86 & 1.69 & $1.71 \mathrm{abcd}$ \\
W117 & & & & & & 2.27 & 2.03 & 1.89 & $1.39 \mathrm{cde}$ \\
A635 & & & & & & & 2.19 & 1.92 & $1.50 \mathrm{bcde}$ \\
A554 & & & & & & & & 2.28 & $1.30 \mathrm{e}$ \\
\hline
\end{tabular}

${ }^{\dagger}$ For parents, means followed by a common letter are not significantly different at $=0.05$, according to Duncan's New Multiple Range Test.

presented in Table 6. Statistical significance was noted for differences among parental lines, for parental lines vs. crosses, and for general and specific combining abilities. The parental lines $v s$. crosses comparison was an indication of heterosis in the $F_{1}$ generation crosses, which suggested a preponderance of genes dominant for tolerance in this set of lines. The variance for general combining ability explained most of the variation for each of the six variables studied, but specific combining ability was also important. As in Experiment 1, additive gene effects were the most important for controlling tolerance but dominance was also important.

The parental and $F_{1}$ generation means and estimates of general and specific combining ability effects are presented in Tables 7 and 8 . Line $\mathrm{C} 103$ possessed the greatest tolerance to $\mathrm{Al}$ toxicity, adn B37, C164, and

Table 8. Estimates of general combining ability (GCA) and specific combining ability (SCA) effects for relative seminal root length (RSRL) of maize generations grown in nutrient solution (Experiment 3)

\begin{tabular}{|c|c|c|c|c|c|c|c|c|c|}
\hline \multirow{2}{*}{$\begin{array}{l}\text { Inbred } \\
\text { lines }\end{array}$} & \multicolumn{8}{|c|}{ SCA effects } & \multirow{2}{*}{$\begin{array}{l}\text { GCA } \\
\text { effects }\end{array}$} \\
\hline & Mo17 & $\mathrm{C} 103$ & $\mathrm{H} 84$ & $\mathrm{C} 164$ & B37 & W117 & A635 & A554 & \\
\hline Mo17 & & 0.1484 & -0.0585 & -0.1158 & 0.2232 & -0.1877 & 0.0965 & -0.1063 & -0.2373 \\
\hline $\mathrm{C} 103$ & & & -0.0694 & -0.1999 & 0.1523 & -0.1699 & 0.0199 & 0.1195 & -0.0847 \\
\hline $\mathrm{H} 84$ & & & & 0.0865 & -0.1380 & -0.0022 & -0.1113 & 0.2926 & 0.0403 \\
\hline $\mathrm{C} 164$ & & & & & -0.0485 & 0.0639 & -0.0952 & 0.2087 & 0.1843 \\
\hline B37 & & & & & & 0.1727 & -0.1563 & -0.2057 & -0.2713 \\
\hline W117 & & & & & & & 0.3895 & -0.2666 & -0.0417 \\
\hline A635 & & & & & & & & -0.1424 & -0.0047 \\
\hline A554 & & & & & & & & & 0.4151 \\
\hline
\end{tabular}

Standard errors of differences: Between two GCA effects $=0.0730$

Between two SCA effects with one common parent $=0.1633$

Between two SCA effects with no parents in common $=0.1461$ 
$\mathrm{H} 84$ tended to be intermediate in Al tolerance. Results of Experiment 3 were somewhat in agreement with those of Experiment 1 in that higher $\mathrm{Al}$ tolerance was noted for $\mathrm{C} 103$ and $\mathrm{H} 84$ and lower Al tolerance was noted for A554, Mo17, and W117. However, the results for A635 and B37 were not consistent. Differences in seed quality between the two experiments may have been important. A635 seedlings with greater vigor were used in Experiment 3 than in Experiment 1. Rhue and Grogan ${ }^{21}$ and Rhue et l. $^{22}$ reported low Al tolerance for A554, B37, and Mo17 tested in their nutrient solution studies.

A554 had the highest general combining ability and consistently performed well in crosses with the other lines. As a line, A554 had a low level of Al tolerance. Similar types of responses were noted for A554 when it was used in crosses by Rhue et al. ${ }^{22}$, who suggested that specific factors existed in the Al non-tolerant A554 which enhanced the expression of $\mathrm{Al}$ tolerance in the $\mathrm{F}_{1}$ generation, but their nature was not understood. In our study, the better than expected performance of A554 for $\mathrm{Al}$ tolerance was expressed particualrly in crosses with the more Al-tolerant lines A635, C103, C16, and H84.

Specific combining ability effects were highest for the crosses $\mathrm{C} 164 \times \mathrm{A} 554, \mathrm{H} 84 \times \mathrm{A} 554$, and $\mathrm{W} 117 \times \mathrm{A} 635$, and lowest for $\mathrm{B} 37 \times \mathrm{A} 554, \mathrm{C} 103 \times \mathrm{C} 164$, and $\mathrm{W} 117 \times \mathrm{A} 554$. The results described for the inheritance of $\mathrm{Al}$ tolerance by many authors were not in complete agreement with the results of the studies reported here. The differences may be explained by differences in genotypes and techniques used. Rhue $^{20}$, Rhue et al. ${ }^{22}$, and Stockmeyer et al. ${ }^{25}$ used $250 \mu \mathrm{mol} \mathrm{Al} \mathrm{L}{ }^{-1}$ and $126 \mu \mathrm{mol} \mathrm{P} \mathrm{L}^{-1}$ in their Al tolerance studies. Thus, the concentrations of $\mathrm{Al}$ and $\mathrm{P}$ used were different from the concentrations used in our inheritance studies $\left(185 \mu \mathrm{mol} \mathrm{Al} \mathrm{L}{ }^{-1}\right.$ and $\left.45 \mu \mathrm{mol} \mathrm{PL}^{-1}\right)$. The methods Rhue and colleagues ${ }^{20,21,22,25}$ used to assess $\mathrm{Al}$ tolerance were also different because they usually separated plants in the $F_{2}$ and backcross generations into classes as well as using root growth as the criterion for separation. Also, the seedlings were transplanted to treatments earlier (2to 3-day old seedlings) compared to our study (7-day-old seedlings).

Silva ${ }^{24}$ used techniques in which the seeds were germinated in sand and irrigated with nutrient solution containing $2780 \mu \mathrm{mol} \mathrm{Al} \mathrm{L}{ }^{-1}$. Maize seedlings were stressed with $\mathrm{Al}$ at an early stage of germination or were germinated with $\mathrm{Al}$ in some experiments. After 7 days, the root length was measured and relative root lengths were determined by comparing measurements on plants grown with and without $\mathrm{Al}$.

In a study with barley (Hordeum vulgare L.) seedlings, May et al. ${ }^{18}$ concluded that the response of plants to variations in the environment decreased rapidly with the age of the plants. Thawornwong and Van 
Diest ${ }^{26}$ pointed out that young rice (Oryza sativa L.) seedlings were more susceptible to Al toxicity than older plants. Sartain and Kamprath ${ }^{23}$ noted that short-term root elongation studies with soybean cultivars [Glycine $\max$ (L.) Merr.] only took into account the effects of $\mathrm{Al}$ on cell elongation and cell division. However, in another study with soybeans in which selection was made in a population, Hanson and Kamprath ${ }^{12}$ concluded that $\mathrm{Al}$ tolerance based on growth in nutrient solutions apparently identified genetic differences for tolerance in established plants as well as tolerance that appeared unique in the seedling stage. This may account for some of the differences between the results reported in our studies compared to those of the other studies described.

Galvao and Silva ${ }^{8}$ based their evaluations of $\mathrm{Al}$ tolerance in maize on shoot and root dry matter yields, which are not always related to $\mathrm{Al}$ tolerance ${ }^{6,17,14}$. Lopes et al. ${ }^{14}$ and Naspolini et al. ${ }^{19}$ found that the magnitude of general combining ability variances was higher than that of the specific combining ability variances. These results agree with those noted in our study.

It is evident that $\mathrm{Al}$ tolerance in maize is quantitatively inherited in the lines studies. However, the differences in level of $\mathrm{Al}$ tolerance of Brazilian maize inbred lines compared to USA inbred lines ${ }^{16}$ do not eliminate the possibility of a major gene for Al tolerance as described by Silva ${ }^{24}$. Further investigation should be conducted using the more tolerant Brazilian lines in crosses with the less tolerant USA lines.

Several different mechanisms explaining plant $\mathrm{Al}$ tolerance have been described in the literature ${ }^{4,5,6,13}$. It is not clear how these mechanisms are related and which may be the most important in attempting to explain $\mathrm{Al}$ tolerance. Evidence does not support the concept that a single major gene controls Al tolerance; a more complex genetic system is more probable. Perhaps at specific stages of plant development, one mechanism could be more important than another and simple genetic control of $\mathrm{Al}$ tolerance might exist at specific growth stages.

\section{References}

1 Clark R B 1982 Nutrient solution growth of sorghum and corn in mineral nutrition studies. J. Plant Nutr. 5, 1039-1057.

2 Cochran W G and Cox G M 1957 Experimental Designs, 2nd edition. John Wiley \& Sons, New York.

3 Comstock R E and Robinson H F 1948 The components of genetic variance in populations of biparental progenies and their use in estimating the average degree of dominance. Biometrics 4, $254-266$

4 Foy C D, Chaney R L and White M C 1978 The physiology of metal toxicity in plants. Annu. Rev. Plant Physiol. 29, 511-566.

5 Foy C D and Fleming A L 1978 The physiology of plant tolerance to excess available 
aluminum and manganese in acid soils. pp 301-328. In Crop Tolerance to Suboptimal Land Conditions. Ed. G A Jung. Am. Soc. Agron., Madison, WI.

6 Furlani P R 1981 Effects of aluminum on growth and mineral nutrition of sorghum genotypes. Ph.D. Diss., Univ. of Nebraska, Lincoln. Diss. Abstr. 42, 1260B.

7 Furlani P R and Clark R B 1981 Screening sorghum for aluminum tolerance in nutrient solution. Agron. J. 73, 587-594.

8 Galvao J D and Silva J C 1978 Inheritance of aluminum tolerance in the maize variety Piranao. Ceres 25, 71-78. (In Portuguese)

9 Garcia O Jr, da Silva W J and Massei M A S 1979 An efficient method for screening maize inbreds for aluminum tolerance. Maydica 24, 75-82.

10 Gardner C O and Eberhart S A 1966 Analysis and interpretation of the variety cross diallel and related populations. Biometrics 22, 439-452.

11 Griffing B 1965 Concept of general and specific combining ability in relation to diallel crossing systems. Aust. J. Biol. Sci. 9, 463-493.

12 Hanson W D and Kamprath E J 1979 Selection for aluminum tolerance in soybean based on seedling-root growth. Agron J. 71, 581-586.

13 Lafever H N 1981 Genetic differences in plant response to soil nutrient stress. J. Plant Nutr. 4, 89-109.

14 Lopes A L, Magnavaca R, Bahia A F C and Gama E E G 1985 Performance of maize populations for aluminum tolerance in nutrient solution. Brazilian Agric. Res. (In press) (In Portuguese)

15 Magnavaca R 1982 Genetic variability and the inheritance of aluminum tolerance in maize (Zea mays L.). Ph.D. Diss., Univ. of Nebraska, Lincoln. Diss. Abstr. 43, 2073B (1983).

16 Magnavaca R, Gardner C O and Clark R B 1986 Evaluation of inbred maize lines for aluminum tolerance in nutrient solution. pp 189-199. In Genetic Aspects of Plant Mineral Nutrition. Eds. W H Gabelman and B C Loughman. Martinus Nijhoff/Dr. W. Junk Publ., The Hague, The Netherlands.

17 Mather K and Jinks J L 1971 Biometrical Genetics. Cornell Univ. Press, Ithaca, NY.

18 May L H, Chapman F H and Aspinall D 1964 Quantitative studies of root development. Aust. J. Biol. Sci. 18, 25-35.

19 Naspolini V, Bahia A F C, Viana R T, Gama E E G, Vasconcellos C A and Magnavaca R 1981 Performance of inbreds and single crosses of corn in soils under 'cerrado' vegetation. Ciencia Cultura 33, 722-727. (In Portuguese)

20 Rhue R D 1979 Differential aluminum tolerance in crop plants. pp 61-80. In Stress Physiology in Crop Plants. Eds. H Mussell and R C Staples. John Wiley \& Sons, New York.

21 Rhue R D and Grogan C O 1977 Screening Corn for Al tolerance using different $\mathrm{Ca}$ and $\mathrm{Mg}$ concentrations. Agron. J. 69, 75-760.

22 Rhue R D, Grogan C O, Stockmeyer E W and Everett H L 1978 Genetic control of aluminum tolerance in corn. Crop. Sci. 18, 1063-1067.

23 Sartain J B and Kamprath E J 1978 Aluminum tolerance of soybean cultivars based on root elongation in solution culture compared with growth in acid soil. Agron. J. 70, 17-20.

24 Silva W J da 1979 Selection of tolerant corn to aluminum toxicity. pp 107-113. In XIII Annu. Conf. Genetic Society, Jaboticabal, S.P., Brazil. (In Portuguese)

25 Stockmeyer E W, Everett H L and Rhue R H 1978 Aluminum tolerance in maize seedlings as measured by primary root length in nutrient solutions. Maize Genet. Coop. Newsl. 52, 15-16.

26 Thawornwong N and Van Diest A 1974 Influences of high acidity and aluminum on the growth of lowland rice. Plant and Soil 41, 141-159. 